\title{
Normal Cerebral Arteriogram
}

National Cancer Institute

\section{Source}

National Cancer Institute. Normal Cerebral Arteriogram. NCI Thesaurus. Code C28318.

An x-ray of the cerebral arteries that reveals normal results. 